\title{
The problem of nitrogen disposal in the obese
}

\author{
Marià Alemany ${ }^{1,2 *}$ \\ ${ }^{1}$ Department of Nutrition and Food Science, Faculty of Biology, University of Barcelona, Barcelona, Spain \\ ${ }^{2}$ CIBER Nutrition and Obesity, Institute of Health Carlos III, Barcelona, Spain
}

\begin{abstract}
Amino- $\mathrm{N}$ is preserved because of the scarcity and nutritional importance of protein. Excretion requires its conversion to ammonia, later incorporated into urea. Under conditions of excess dietary energy, the body cannot easily dispose of the excess amino-N against the evolutively adapted schemes that prevent its wastage; thus ammonia and glutamine formation (and urea excretion) are decreased. High lipid (and energy) availability limits the utilisation of glucose, and high glucose spares the production of ammonium from amino acids, limiting the synthesis of glutamine and its utilisation by the intestine and kidney. The amino acid composition of the diet affects the production of ammonium depending on its composition and the individual amino acid catabolic pathways. Surplus amino acids enhance protein synthesis and growth, and the synthesis of non-protein-N-containing compounds. But these outlets are not enough; consequently, less-conventional mechanisms are activated, such as increased synthesis of $\mathrm{NO}^{\bullet}$ followed by higher nitrite (and nitrate) excretion and changes in the microbiota. There is also a significant production of $\mathrm{N}_{2}$ gas, through unknown mechanisms. Health consequences of amino-N surplus are difficult to fathom because of the sparse data available, but it can be speculated that the effects may be negative, largely because the fundamental $\mathrm{N}$ homeostasis is stretched out of normalcy, forcing the $\mathrm{N}$ removal through pathways unprepared for that task. The unreliable results of hyperproteic diets, and part of the dysregulation found in the metabolic syndrome may be an unwanted consequence of this $\mathrm{N}$ disposal conflict.
\end{abstract}

Key words: Amino acids: Ammonia: Metabolic syndrome: Obesity: Urea: Nitrogen excretion

\section{Introduction}

When compared with the metabolism of carbohydrates and lipids, amino acid metabolism in man has been only sparsely studied in relation to overall energy metabolism. The roles of protein in starvation ${ }^{(1,2)}$ and malnutrition ${ }^{(3,4)}$, however, have received more attention; however, in any case, our actual knowledge of $\mathrm{N}$ metabolism in man is far more limited than the detailed information available on energy partition between carbohydrate (glucose) and lipids, including their regulation systems. Curiously, the study of proteins has been neglected despite being a key nutritional source of energy. Probably, the present situation of limited knowledge is a compounded consequence of the relatively large number of different molecular species, their easy interconversion, the multiple catabolic paths followed by their hydrocarbon skeletons, the methodological difficulties of tracing the fate of $\mathrm{N}$, its close relationship with protein turnover, a multiplicity of functional amino acid pools coupled with an active interorgan metabolism, and last, but not least, an excessively sketchy knowledge of their catabolic paths and regulation in man (mammals).
Irrespective of the lack of information, the manipulation of protein content of diets has been actively developed for at least half a century, mainly by using hyperproteic verylow-energy diets for the treatment of obesity ${ }^{(5,6)}$, with serious problems often arising from their application ${ }^{(7)}$. There has been a considerable utilisation of lowcarbohydrate diets, in which the protein component is conspicuous $^{(8,9)}$, but most of the discussion of their effects has been centred on their ketogenic (i.e. lipid, absence of carbohydrate) nature ${ }^{(10)}$, the amino acids essentially being considered potential gluconeogenic substrates ${ }^{(11)}$, with little impact on protein synthesis ${ }^{(12)}$. More recently, the use of hyperproteic diets ${ }^{(13)}$ is again on the rise, but we still lack the necessary basic knowledge to interpret the results obtained, largely because of few systematic analyses and the continued stress on their ketogenic nature ${ }^{(8,9)}$.

However, under conditions of abundant food supply, the main question is not how amino acids fare under conditions of low energy availability, but the contrary: how the metabolic machinery can override the strong protective mechanisms preventing $\mathrm{N}$ wasting under conditions of excess energy (i.e. lipid, carbohydrate and protein) intake. There are few studies on how amino acids are 
used as substrates, especially on the fate of $\mathrm{N}$ under conditions of excess energy intake or obesity. In the present review, the main questions posed by the combination of excess energy and amino- $\mathrm{N}$ availability are analysed under the light of the scarce information available.

\section{Amino acids as energy substrates: amino-nitrogen sparing}

One of the most significant differences between what our ancestors ate (i.e. the diet for which our digestive system and metabolic energy partitioning are geared and optimised) and the present-day diet is, in addition to the overwhelming abundance of lipid, the constant presence of protein, with a relatively high proportion of high-quality protein. The tandem lipid-animal protein is substituting progressively complex carbohydrate-low-quality plant protein as the main dietary staple. The proportion of protein energy $v$. total energy intake is not too much different today from the ancestral diet ${ }^{(14)}$, but the total amount of energy (after correcting for exercise) is higher, as is the proportion of essential amino acids ${ }^{(15)}$, whilst the relationship between dietary amino acids $v$. glucose derived from dietary sources tends to change as a direct consequence of the substitution of starches by fats ${ }^{(16)}$.

Our starvation resistance-prone mechanisms of adaptation preserve the use of amino acids as energy substrate when there is sufficient energy in the gut ${ }^{(17)}$. In addition, both amino acids and glucose are spared when (if) the availability of lipid is high ${ }^{(18,19)}$. In consequence, a diet rich in energy and lipids, with a sizeable proportion of easily digestible protein, rich in essential amino acids, will necessarily result in difficulties to process and oxidise the amino acid surplus, since we are metabolically conditioned to actively preserve them. However, under excess-energy diets (including protein), it is no longer necessary to retain so much amino-N and essential amino acids. Amino acids are used for energy when in relative excess ${ }^{(20,21)}$, but the even higher availability of energy from other sources strongly limits our metabolic machinery to do so ${ }^{(22)}$.

Amino acid catabolism tends to retain 2-amino-N, largely because most amino acid hydrocarbon skeletons are oxidised after transamination (typically to 2-oxoglutarate/ glutamate). However, a few amino acids yield directly ammonia (Table 1). A quantitative analysis of several common food proteins shows that, as expected, the theoretical direct yield of 2 -amino- $\mathrm{N}$ is much higher than that of direct ammonium production (Table 2). Thus, the parity needed to synthesise our main $\mathrm{N}$ excretion product, urea, requires (in a dietary equilibrium) the additional conversion of a varying proportion of dietary 2 -amino-N to ammonium to reach the required (1:1) balance. The ratio amino-N:ammonium-N in most dietary proteins is close to 2 (Table 2), which leaves a wide margin for preservation of $\mathrm{N}$ under conditions of starvation, but in the end requires the mineralisation of about half of all amino- $\mathrm{N}$ to ammonia under normal feeding conditions.
When active (exercise), muscle uses most of the body energy available: its standard feed is glucose, but blood lipids (fatty acids) limit glucose uptake and favour fatty acid oxidation (insulin resistance) ${ }^{(23)}$. Some amino acids are oxidised in muscle (especially branched-chain ${ }^{(24)}$ ) in the postprandial state to save glucose, but excess energy hampers the process and its timing, since in fact there is no real scarcity of glucose. Amino-N conversion into ammonia is largely done in the liver and muscle through the purine nucleotide cycle ${ }^{(25)}$, and its operation is both linked to active glycolysis ${ }^{(26)}$ and increased AMP levels (i.e. low ATP availability, partly compensated by the action of adenylate kinase ${ }^{(27)}$; thus, under excess energy availability, the cycle is largely idle. Glutamate dehydrogenases play a key role in ammonium metabolism in micro-organisms ${ }^{(28)}$, and in the muscle of invertebrates ${ }^{(29)}$. However, Their role in ammoniagenesis in mammalian muscle is limited, because of the predominance of the purine nucleotide cycle $^{(30)}$ in this role, and the low presence of the enzyme compared with the liver ${ }^{(31)}$, unaltered under starvation $^{(32)}$. In the liver (and kidney), the activity of glutamate dehydrogenase is considerable ${ }^{(31)}$, but its function is clearly that of resynthesising glutamate from 2-ketoglutaratre and excess ammonia, as determined by direct studies and the analysis of its kinetic constrictions ${ }^{(33-35)}$.

\section{Equilibrium between amino-nitrogen and ammonia for urea synthesis}

Thus, in muscle there is no other major way to produce ammonia than the purine nucleotide cycle $^{(30)}$. In consequence the muscle cannot use amino acids as an energy source in significant amounts ${ }^{(36)}$ and to use their $\mathrm{N}$ to produce and release glutamine. This is an important question, since glutamine is the main form of blood transport of ammonia, towards the splanchnic bed ${ }^{(37)}$, i.e. intestine and kidney; there, glutaminases free the ammonia again for its ultimate disposal as urea ${ }^{(38)}$, or as urinary ammonium ion ${ }^{(39)}$. Lower muscle synthesis of glutamine results, then, in lower splanchnic synthesis of carbamoyl-P, insufficient to maintain an adequate flow of urea synthesis (Fig. 1). Alternative sources of ammonium, such as the microbiota ${ }^{(40,41)}$, which is in part derived from glutamine ${ }^{(42,43)}$, and the direct ammoniagenic amino acids cited above (serine, threonine, glycine), help maintain a steady albeit diminished rate of urea synthesis in the intestine-liver system, a rate insufficient to cope with the excess 2 -amino-N pool generated by the diet and limited amino acid disposal.

High amino acids in conjunction with high energy availability can generate a paradoxical scarcity of ammonia, retaining a large and unshrinkable pool of amino-N because the mechanisms that protect its conversion to ammonia remain unaffected, and are both efficient and effective (and potentially crippling). In the metabolic syndrome (and in general, in energy-rich feeding), urea 
Table 1. Main amino acid (AA) catabolism pathways in man (adapted from Ferrer-Lorente et al. $\left.{ }^{(130)}\right)^{\star}$

\begin{tabular}{|c|c|c|c|c|c|c|}
\hline AA & Flow & Pathway & $-\mathrm{NH}_{2}$ & Mean & $\mathrm{NH}_{3}$ & Mean \\
\hline \multirow[t]{4}{*}{ Gly } & 60 & [Gly-cleavage system] $\rightarrow$ methylene-THF $\rightarrow$ methenyl-THF $\rightarrow$ formate & 0 & 0.35 & 1 & 0.60 \\
\hline & 35 & [trans to] glyoxylate $\rightarrow$ glycolate & 1 & & 0 & \\
\hline & 10 & [via UC conjugated with Arg] to creatine $\rightarrow$ creatine-P $\rightarrow$ creatinine & 0 & & 0 & \\
\hline & 5 & Other: excretion intact or as peptides, conjugation of xenobiotics and hormones & 0 & & 0 & \\
\hline Ala & 100 & {$[$ trans to $]$ pyr $\rightarrow$ AcCoA $\rightarrow[K C]$} & 1 & 1.00 & 0 & 0.00 \\
\hline \multirow[t]{3}{*}{ Ser } & 90 & {$[$ Ser-dehydratase to $]$ pyr $\rightarrow$ AcCoA $\rightarrow[K C]$} & 0 & 0.05 & 1 & 0.95 \\
\hline & 5 & [trans to] pyr-OH $\rightarrow$ AcCoA $\rightarrow[\mathrm{KC}]$ & 1 & & 0 & \\
\hline & 5 & [cleavage to] Gly +1-C & 0 & & 1 & \\
\hline \multirow[t]{2}{*}{ Cys } & 90 & [trans + desulfuration to $]$ pyr $\rightarrow$ AcCoA $\rightarrow[K C]$ & 0 & 0.00 & 1 & 0.90 \\
\hline & 10 & Other: conversion to taurine & 0 & & 0 & \\
\hline Met & 100 & $\begin{array}{l}\text { [conjugated with ATP] } \rightarrow \text { S-adenosylMet } \rightarrow \text { [de-methylation }(\rightarrow 1-\mathrm{C}) \text { to] Hcys } \rightarrow \text { [conjugated with Ser] } \rightarrow \text { cystathionine } \\
\quad \rightarrow(\text { pyr } \rightarrow \text { AcCoA } \rightarrow[\mathrm{KC}])+\text { oxobutyrate } \rightarrow \text { propionylCoA } \rightarrow \text { succ } \rightarrow \text { OAA } \rightarrow \text { pyr } \rightarrow \text { AcCoA } \rightarrow[\mathrm{KC}]\end{array}$ & 0 & 0.00 & 1 & 1.00 \\
\hline \multirow[t]{2}{*}{ Thr } & 95 & {$[$ Thr dehydratase to $]$ oxobutyrate $\rightarrow$ propionyICoA $\rightarrow$ succ $\rightarrow$ OAA $\rightarrow$ pyr $\rightarrow$ AcCoA $\rightarrow[K C]$} & 0 & 0.00 & 1 & 1.00 \\
\hline & 5 & [Thr aldolase to] Gly + acetaldehyde & 0 & & 1 & \\
\hline \multirow[t]{2}{*}{ Asp } & 50 & [trans to] OAA $\rightarrow$ pyr $\rightarrow$ AcCoA $\rightarrow[K C]$ & 1 & 0.50 & 0 & 0.50 \\
\hline & 50 & {$[$ via PNC or UC to] fumarate $\rightarrow$ OAA $\rightarrow$ pyr $\rightarrow$ AcCoA $\rightarrow[\mathrm{KC}]$} & 0 & & 1 & \\
\hline Asn & 100 & [asparaginase to] Asp & 1 & 1.00 & 1 & 1.00 \\
\hline \multirow[t]{2}{*}{ Glu } & 97 & [trans to] oxoglutarate] $\rightarrow \mathrm{OAA} \rightarrow \mathrm{pyr} \rightarrow \mathrm{AcCoA} \rightarrow[\mathrm{KC}]$ & 1 & 1.00 & 0 & 0.00 \\
\hline & 3 & [decarboxylation to] $\gamma$-aminobutyrate $\rightarrow$ succ $\rightarrow$ OAA $\rightarrow$ pyr $\rightarrow$ AcCoA $\rightarrow[K C]$ & 1 & & 0 & \\
\hline Gln & 100 & [glutaminase to] Glu & 1 & 1.00 & 1 & 1.00 \\
\hline \multirow[t]{3}{*}{ Pro } & 50 & [dehydrogen to] pyrroline-carboxylate $\rightarrow$ Glu & 1 & 0.95 & 0 & 0.00 \\
\hline & 45 & [oxid to] pyrroline-carboxylate $\rightarrow$ Glu & 1 & & 0 & \\
\hline & 5 & Excretion. Intact or as peptides & 0 & & 0 & \\
\hline \multirow[t]{3}{*}{ Hyp } & 45 & $\begin{array}{l}\text { [dehydrogen to] OH-pyrroline-carboxylate } \rightarrow \text { erythro OH-Glu } \rightarrow \text { OH-oxoglutarate } \rightarrow \text { (glyoxylate } \rightarrow \text { glycolate) }+(\text { pyr } \rightarrow \\
\quad \text { AcCoA } \rightarrow[\mathrm{KC}] \text { ) }\end{array}$ & 1 & 0.90 & 0 & 0.00 \\
\hline & 45 & $\begin{array}{l}\text { [oxid to] pyrroline-carboxylate } \rightarrow \text { erythro OH-Glu } \rightarrow \text { OH-oxoglutarate } \rightarrow \text { (glyoxylate } \rightarrow \text { glycolate) }+(\text { pyr } \rightarrow \text { AcCoA } \rightarrow \\
{[\mathrm{KC}] \text { ) }}\end{array}$ & 1 & & 0 & \\
\hline & 10 & Excretion. Intact or as peptides & 0 & & 0 & \\
\hline Val & 100 & [trans to] oxoisovalerate $\rightarrow$ isobutyrylCoA $\rightarrow[\mathrm{BO}] \rightarrow$ succCoA $\rightarrow$ succ $\rightarrow$ OAA $\rightarrow$ pyr $\rightarrow$ AcCoA $\rightarrow[\mathrm{KC}]$ & 1 & 1.00 & 0 & 0.00 \\
\hline Leu & 100 & {$[$ trans to] oxoisocaproate $\rightarrow[\mathrm{BO}] \rightarrow(\mathrm{AcCoA} \rightarrow[\mathrm{KC}])+\mathrm{AcAc} \rightarrow \mathrm{AcCoA} \rightarrow[\mathrm{KC}]$} & 1 & 1.00 & 0 & 0.00 \\
\hline Ile & 100 & $\begin{array}{l}\text { [trans to] oxomethylvalerate } \rightarrow \text { methylbutyrylCoA } \rightarrow[\mathrm{BO}] \rightarrow(\mathrm{AcCoA} \rightarrow[\mathrm{KC}])+\text { propionylCoA } \rightarrow \text { succ } \rightarrow \text { OAA } \rightarrow \text { pyr } \\
\quad \rightarrow \mathrm{AcCoA} \rightarrow[\mathrm{KC}]\end{array}$ & 1 & 1.00 & 0 & 0.00 \\
\hline \multirow[t]{2}{*}{ Lys } & 90 & [conjugated with oxoglutarate] $\rightarrow$ saccharopine $\rightarrow(\mathrm{Glu})+$ oxoadipate $\rightarrow$ AcAcCoA $\rightarrow$ AcCoA $\rightarrow[\mathrm{KC}]$ & 2 & 1.80 & 0 & $0 \cdot 10$ \\
\hline & 10 & [deamination to] pipecolate $\rightarrow$ oxoadipate $\rightarrow$ AcAcCoA $\rightarrow$ AcCoA $\rightarrow[K C]$ & 1 & & 1 & \\
\hline \multirow[t]{2}{*}{ His } & 95 & [deamination to] urocanate $\rightarrow$ formiminoGlu $\rightarrow[1-\mathrm{C}]+$ Glu & 1 & 0.95 & 2 & 1.90 \\
\hline & 5 & Other: excretion/conversion to histamine & 0 & & 0 & \\
\hline Arg & 100 & [via UC to] Orn $\rightarrow$ Glu-semi-aldehyde $\rightarrow$ pyrroline-carboxylate $\rightarrow$ Glu & 1 & 1.00 & 0 & 0.00 \\
\hline \multirow[t]{2}{*}{ Trp } & 70 & $\begin{array}{l}\text { [oxid to] kynurenine }(+ \text { formate }) \rightarrow(\mathrm{Ala} \rightarrow \mathrm{pyr} \rightarrow \mathrm{AcCoA} \rightarrow[\mathrm{KC}])+\text { oxoadipate } \rightarrow \text { crotonyl-CoA } \rightarrow[\mathrm{BO}] \rightarrow \text { AcCoA } \\
\quad \rightarrow[\mathrm{KC}]\end{array}$ & 2 & $1 \cdot 70$ & 0 & 0.00 \\
\hline & 30 & [trans to] indol-pyruvate $\rightarrow$ indol-acetate (excreted) & 1 & & 0 & \\
\hline \multirow[t]{2}{*}{ Tyr } & 95 & $\begin{array}{l}\text { [trans to] OH-phenyl-pyruvate } \rightarrow \text { homogentisate } \rightarrow \text { (fumarate } \rightarrow \text { OAA } \rightarrow \text { pyr } \rightarrow \text { AcCoA } \rightarrow[K C])+\mathrm{AcAc} \rightarrow \text { AcCoA } \\
\quad \rightarrow[\mathrm{KC}]\end{array}$ & 1 & 0.95 & 0 & 0.00 \\
\hline & 5 & Other: [via dihydroxyphenylalanine. incorporation into] melanin, or catecholamines; excretion & 0 & & 0 & \\
\hline \multirow[t]{2}{*}{ Phe } & 95 & [oxid to] Tyr & 1 & 1.00 & 0 & 0.00 \\
\hline & 5 & Other: largely [trans to] and excretion as phenylpyruvate) & 1 & & 0 & \\
\hline
\end{tabular}

THF, tetrahydrofolate; [trans to], transamination to; UC, urea cycle; AcCoA, acetyl-coenzyme A; [KC], Krebs or tricarboxylic acid cycle; pyr, pyruvate; [1-C], one-carbon pathways (essentially via THF); succ, succinate; OAA, oxaloacetate; [dehydrogen to], dehydrogenation to; [oxid to], oxidation to; PNC, purine nucleotide cycle; [BO], $\beta$-oxidation pathway; AcAc, acetoacetate; AcAcCoA, acetoacetyl-coenzyme A.

All values are estimations based on the scant data available from human subjects and other mammals; flow of amino acid catabolism via a given path depends largely on the size of amino-N pool, energy availability, metabolic needs and the relative abundance of the amino acid (essential amino acids). 
Table 2. Amino acid (AA) content of a number of common food proteins, showing the $-\mathrm{NH}_{2}: \mathrm{NH}_{3}$ ratio that would be theoretically generated from the complete oxidation in the body of its constituent amino acids ${ }^{\star}$

\begin{tabular}{|c|c|c|c|c|c|}
\hline & $\begin{array}{c}\text { AA content } \\
\text { (mmol/g protein) }\end{array}$ & $\begin{array}{c}-\mathrm{NH}_{2}(\mathrm{mmol} / \mathrm{g} \\
\text { protein) }\end{array}$ & $\begin{array}{c}\mathrm{NH}_{3}(\mathrm{mmol} / \mathrm{g} \\
\text { protein) }\end{array}$ & $\begin{array}{c}-\mathrm{NH}_{2}: \mathrm{NH}_{3} \\
\text { ratio }\end{array}$ & $\begin{array}{r}\text { 'Excess }-\mathrm{NH}_{2} \text { ' } \\
\left(\% \text { of }-\mathrm{NH}_{2}\right)\end{array}$ \\
\hline Cheese & 888 & 775 & 296 & $2 \cdot 61$ & 62 \\
\hline Potatoes & 912 & 774 & 312 & 2.48 & 60 \\
\hline Maize 1 & 928 & 766 & 309 & 2.48 & 60 \\
\hline Maize 2 & 935 & 771 & 316 & $2 \cdot 44$ & 59 \\
\hline Cows' milk & 884 & 758 & 319 & $2 \cdot 38$ & 58 \\
\hline Pork & 908 & 782 & 340 & $2 \cdot 30$ & 57 \\
\hline Spinach & 923 & 748 & 337 & $2 \cdot 22$ & 55 \\
\hline Beef & 933 & 770 & 349 & $2 \cdot 21$ & 55 \\
\hline Pilchard fish & 919 & 770 & 348 & $2 \cdot 21$ & 55 \\
\hline Haddock fish & 908 & 773 & 351 & $2 \cdot 20$ & 55 \\
\hline Lamb meat & 928 & 764 & 351 & $2 \cdot 18$ & 54 \\
\hline Peas & 896 & 750 & 344 & $2 \cdot 18$ & 54 \\
\hline Cassava & 875 & 734 & 339 & $2 \cdot 16$ & 54 \\
\hline Lentils & 900 & 745 & 347 & $2 \cdot 14$ & 53 \\
\hline Chickpeas & 893 & 736 & 345 & $2 \cdot 13$ & 53 \\
\hline Soyabeans & 899 & 744 & 352 & $2 \cdot 11$ & 53 \\
\hline Mollusks & 920 & 743 & 356 & 2.09 & 52 \\
\hline Wheat & 903 & 734 & 351 & 2.09 & 52 \\
\hline Chicken & 909 & 748 & 360 & 2.08 & 52 \\
\hline Crustaceans & 928 & 742 & 357 & 2.08 & 52 \\
\hline Tuna fish & 903 & 774 & 375 & 2.06 & 52 \\
\hline Polished rice & 915 & 723 & 357 & 2.03 & 51 \\
\hline Carrots & 908 & 750 & 374 & $2 \cdot 01$ & 50 \\
\hline Beans & 907 & 743 & 373 & 1.99 & 50 \\
\hline Hens' eggs & 914 & 713 & 359 & 1.98 & 50 \\
\hline Cabbage & 944 & 724 & 375 & 1.93 & 48 \\
\hline Sesame & 898 & 698 & 362 & 1.93 & 48 \\
\hline Hazelnuts & 915 & 680 & 377 & $1 \cdot 81$ & 45 \\
\hline Apples & 928 & 743 & 423 & 1.75 & 43 \\
\hline
\end{tabular}

\footnotetext{
* The data have been calculated from standard protein amino acid composition tables ${ }^{(131)}$ and the yield in free ammonium and transaminable 2 -amino groups resulting from the complete catabolism of these amino acids (Table 1). Since urea excretion requires equal proportions of amino and ammonium, any $-\mathrm{NH}_{2}: \mathrm{NH}_{3}$ ratio above 1.00 represents a relative excess of amino groups, which may be further converted to ammonium via the purine nucleotide cycle or (in certain tissues and physiological conditions) by glutamate dehydrogenase. The ammonium yield of the proteins listed may be underestimated, since most of the data gathered give a combined Glu + Gln (GIx) value in the overall analyses. From the analysis of whole rat protein $^{(132)}$ in which amide-N was analysed separately, we assumed, conservatively, and for the sake of these calculations only, that half the GlX values corresponded to Gln and half to Glu; this correction has been included in the calculations and is reflected in the data shown in the Table.
}

synthesis is decreased $^{(44)}$, but there is not - either - a massive accumulation of body- $\mathrm{N}^{(45)}$. Amino acids tend to be preserved in spite of excess energy availability ${ }^{(46)}$, but in any case, the excess $\mathrm{N}$ is eventually lost, albeit not in the canonical way of urea formation ${ }^{(47)}$. A small but significant proportion of $\mathrm{N}$ is excreted as $\mathrm{N}_{2}$ gas ${ }^{(48,49)}$ by means of, so far, unknown pathways. In addition there is an increased (but relatively small) loss of dietary amino- $\mathrm{N}$ in the form of urinary nitrate and nitrite ${ }^{(50)}$. Obligatory $\mathrm{N}$ losses also include urinary losses of uric acid (from purine catabolism ${ }^{(51)}$ ), creatinine and small proportions of peptides and amino acids, as well as the ammonium ion, excreted by the kidney (especially in acidosis) ${ }^{(52)}$. Small amounts of ammonium may be also excreted by the lungs ${ }^{(53)}$.

Muscle also accumulates fat, near mitochondrial clusters (C Cabot, K Pouillot, S Roy, MM Romero, R Vilà, MM Grasa, M Esteve, JA Fernández-López, M Alemany and X Remesar, unpublished results) and adapts itself to the utilisation of this main substrate (as well as to glucose, but to a lower extent) ${ }^{(54,55)}$. Exercise facilitates the massive utilisation of energy and streamlines the oxidation of fats ${ }^{(56)}$, but also restores in part the production of ammonium via the purine nucleotide cycle ${ }^{(57)}$, thus increasing the flow of glutamine to the splanchnic bed. However, a large proportion of glucose, lipids and amino acids can not be taken up by any of the above cited systems, leaving them unused and in high serum concentrations, waiting for their storage as fat in the last-recourse energy pool: white adipose tissue.

\section{The nitric oxide pathway}

$\mathrm{NO}^{*}$ is synthesised from arginine by $\mathrm{NO}^{*}$ synthases, yielding citrulline $^{(58)}$. Excess $\mathrm{N}$ availability increases the synthesis of ornithine $^{(59)}$, including the intermediate step of acetylglutamate synthesis ${ }^{(60)}$, which is also a key regulator of carbamoyl-P synthase 2 , and thus also participates in the regulation of ammonium disposal ${ }^{(61)}$. In consequence, higher amino-N levels may increase those of arginine, irrespective of low carbamoyl-P (i.e. low ammonium) availability, shunting the $\mathrm{NO}^{\circ}$ cycle from arginine to citrulline and leaving out ornithine (and the synthesis of urea) (Fig. 2 (a) and (b)) ${ }^{(62)}$. In cells that do not have a fully operative urea cycle, the eventual regulation is even easier since it is largely dependent on arginine availability ${ }^{(63)}$.

It may be expected, then, that under high energy and amino-N availability, the low ammonia concentrations ${ }^{(64)}$ 


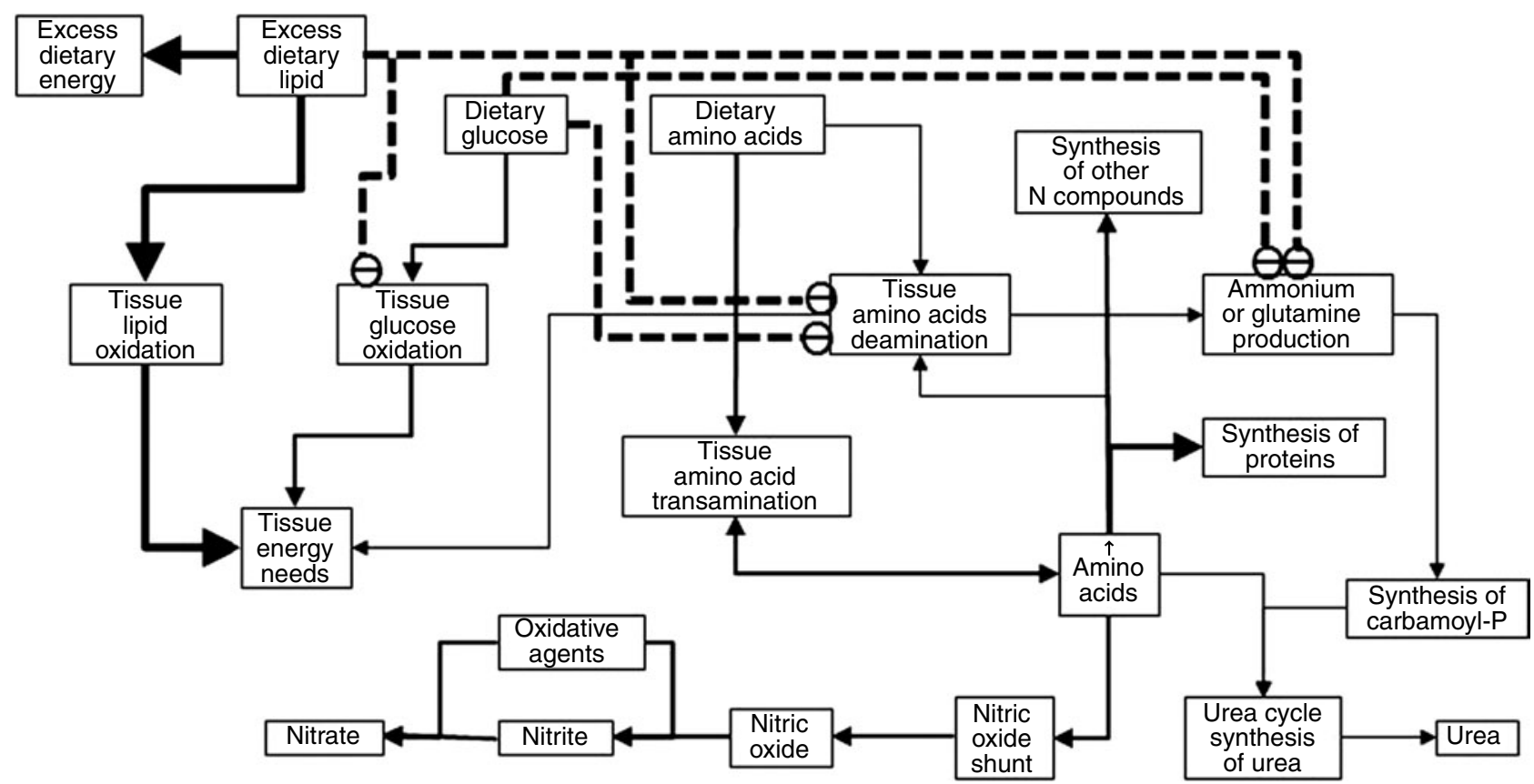

Fig. 1. Effect of excess dietary lipid on the main paths of $\mathrm{N}$ catabolism, driving to a decrease in the operation of the urea cycle because of lack of conversion of 2-amino- $\mathrm{N}$ to ammonium.

can not sustain an effective excretion of $\mathrm{N}$ through the urea cycle $^{(65)}$, indirectly favouring an increased activity of the NO synthesis shunt. The excess $\mathrm{NO}^{*}$ in blood vessels (derived from the activity of erythrocyte and endothelial NO synthases) ${ }^{(66)}$ may initially raise the blood flow, at least locally, increasing the availability of oxygen and substrates to the surrounding cells ${ }^{(67)}$.

$\mathrm{NO}^{\circ}$ is highly reactive and interacts with specific proteins, such as guanylate cyclase ${ }^{(68)}$, increasing the production of cyclic GMP which activates protein kinase $\mathrm{G}(\mathrm{PKG})^{(69)}$ which, in turn, relaxes the smooth muscle of small vessels and thus increases blood flow and lowers arterial tension ${ }^{(70)}$. This is the main recognised function of $\mathrm{NO}^{\cdot(71)}$, but $\mathrm{NO}^{\circ}$ is also able to bind cysteine residues of other proteins, such as protein kinase A (PKA) ${ }^{(72)}$, which may induce a phantom adrenergic stimulation (i.e. without the intervention of catecholamines or CAMP) ${ }^{(73)}$.

Cytochrome $c$ also efficiently oxidises $\mathrm{NO}^{\circ}$ to nitrite ${ }^{(74)}$. Most of the NO', however, rapidly reacts with oxyhaemoglobin, eventually oxidising $\mathrm{NO}^{*}$ to nitrate ${ }^{(75)}$. Other highly reactive $\mathrm{NO}_{\mathrm{x}}$ compounds, such as peroxynitrite ${ }^{(76)}$, are formed by further oxidation with reactive oxygen species. Part of these nitrogen oxides react with proteins, fatty acids and other compounds yielding nitro-derivatives ${ }^{(77,78)}$, often short-lived, but which can cause permanent structural changes ${ }^{(79)}$.

\section{Nitrite and other forms of nitrogen excretion}

In the obese, the overall production and levels of $\mathrm{NO}^{\circ}$ are increased $^{(80)}$, as is its loss in the air breathed ${ }^{(81)}$, but there is a marked decrease in the excretion of urea ${ }^{(44)}$.
A significant part of the difference in the $\mathrm{N}$ balance is made up of $\mathrm{N}_{2}$ gas ${ }^{(45,47,82)}$. A possible source is the reaction of nitrite and free amino acids, which in an acidic medium yield $\mathrm{N}_{2}$ gas and 2-hydroxyacids ${ }^{(83)}$; this reaction has been described to occur in the stomach lumen ${ }^{(84)}$. However, this reaction can hardly explain the large discrepancies found in $\mathrm{N}$ balances. There must be another - larger - source of $\mathrm{N}_{2}$ gas integrated in the amino acid metabolism, which so far has not been discovered. We can hypothesise the existence of an 'emergence' pathway, shunting the action of $\mathrm{NO}^{\circ}$ synthases towards the reaction of arginine with nitrite, yielding citrulline and $\mathrm{N}_{2}$ gas under acidotic conditions. This way, nitrite, the main active product of $\mathrm{NO}^{\circ}$ synthesis, would be rapidly removed and, at the same time, the excess 2-amino- $\mathrm{N}$ would be decreased at the expense of aspartate-derived arginine guanido-N; unfortunately, no enzyme has been found (so far) able to carry out this reaction, which nevertheless is known to proceed spontaneously under low $\mathrm{pH}$ conditions ${ }^{(83)}$.

Glucocorticoids may elicit counteractive actions ${ }^{(85)}$ to inhibit NO${ }^{\circ}$ synthesis, but catecholamines increase its production $^{(86)}$. It is unclear whether $\mathrm{NO}^{-}$overproduction in the obese can be a consequence of leptin-related catecholamine vasoconstriction ${ }^{(87)}$, a consequence of enhanced NO ${ }^{*}$ synthesis through activation of endothelial or inducible $\mathrm{NO}^{\circ}$ synthases $^{(88)}$, or a lower bioavailability of $\mathrm{NO}^{\circ}$ favouring its increased synthesis ${ }^{(89,90)}$.

Nitrite is considered a stabilised form of $\mathrm{NO}^{\cdot(91)}$, which can yield $\mathrm{NO}^{\circ}$ under hypoxic conditions by reacting with $\mathrm{Hb}^{(92-94)}$, thus helping increase blood flow to hypoxic $\operatorname{areas}^{(95)}$. Nitrite is also a source of $\mathrm{NO}^{\circ}$ in the alimentary canal $^{(96,97)}$; it is largely the product of reduction by the oral 
(a)

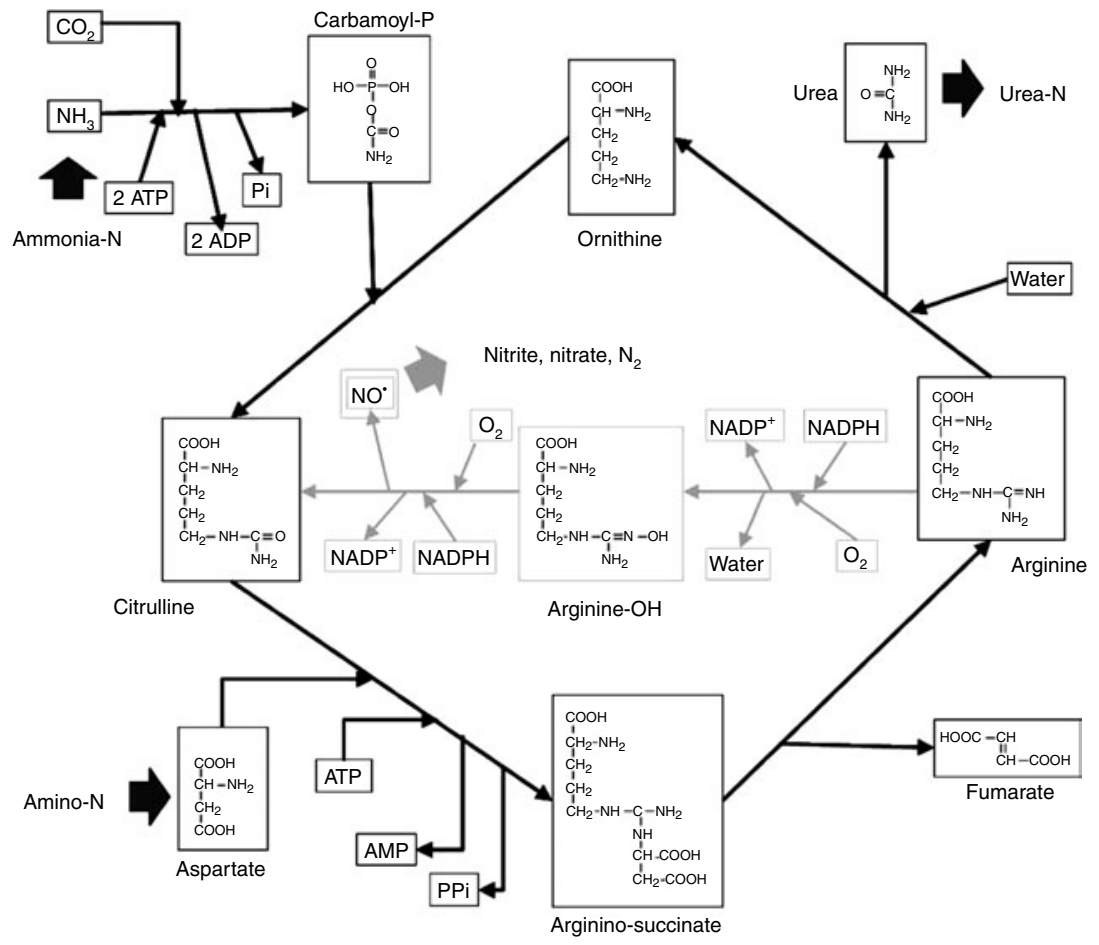

(b)

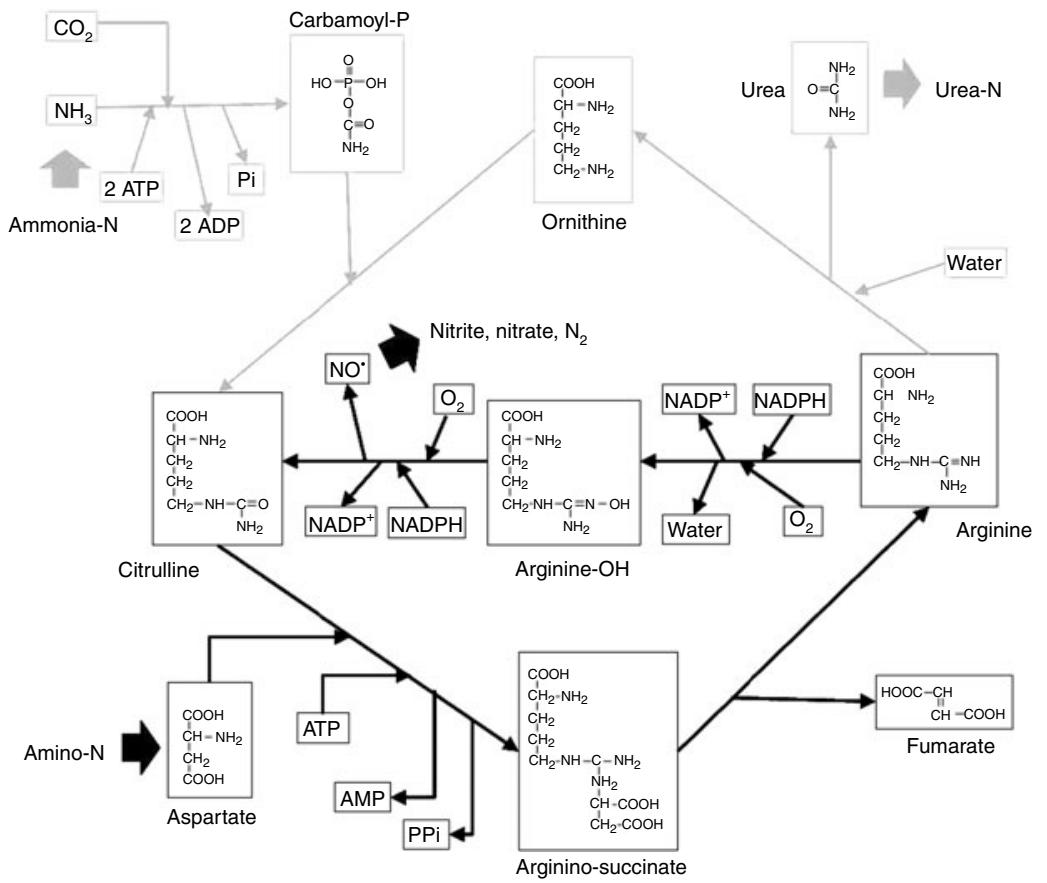

Fig. 2. Possible mechanism of activation of the $\mathrm{NO}^{\circ}$ shunt under high energy availability-low ammonium production. (a) Urea cycle function under full operation, i.e. enough ammonium to produce carbamoyl-P and an adequate supply of 2-amino- $\mathrm{N}$ through aspartate. (b) Enhancement of the operation of the NO ${ }^{\circ}$ shunt of the urea cycle under limited supply of ammonium (in the form of carbamoyl-P), but maintained supply of 2-amino- $\mathrm{N}$ through aspartate. Pi, inorganic phosphate; $\mathrm{PPi}$, inorganic pyrophosphate.

biota of nitrate secreted by salivary glands ${ }^{(98)}$. Nitrite-derived $\mathrm{NO}^{*}$ also kills bacteria in the stomach $^{(99)}$; in this acidic medium, nitrite reacts with free amino acids yielding $\mathrm{N}$-nitroso-proline from arginine ${ }^{(100)}$, as well as $\mathrm{N}_{2}$ as indicated above ${ }^{(84)}$.

The 'obese' microbiota ${ }^{(101,102)}$ is probably a consequence of this magnified effect of $\mathrm{NO}_{\mathrm{x}}^{(103)}$; changes in the gut microbial ecosystem and composition also influence the relationships with the host through modulation of the immune response ${ }^{(104,105)}$. The relative abundance of protein debris in the intestine, a consequence of diets rich in lipid and protein, together with relatively scarce fibre and polysaccharides, also affects the composition of the microbiota, increasing the share of amino acid-related catabolism in the 
process of formation of stool ${ }^{(106,107)}$. The resulting higher $\mathrm{pH}$, and the production of amines through amino acid decarboxylation $^{(107)}$, higher proportions of amines, ammonium, as well as amine- and sulfide-related catabolites may also help induce the development of intestinal cancer ${ }^{(108)}$.

\section{Health consequences of hampered nitrogen excretion in the obese}

The main problem posed by this question is the almost absolute lack of information about the human patterns of $\mathrm{N}$ excretion in overnutrition, obesity and the metabolic syndrome. It has been found that a relative increase in dietary protein at the expense of carbohydrates facilitates the loss of weight ${ }^{(109,110)}$, but we only know the short-term macroscopic changes; the dynamics of 2-amino-N under these conditions has not been studied.

We have mechanisms to adjust amino acid catabolism to their relative abundance with respect to glucose ${ }^{(17)}$, but the large presence of lipids in the diet alters everything. Ketogenic diets favour the excretion of ammonium in the urine to counter the acidosis produced by ketone bodies ${ }^{(111,112)}$, and increase liver gluconeogenesis from amino acids ${ }^{(113)}$, but the problem of conversion of amino-N to ammonium remains. The possible negative effects of a few truly hyperproteic (i.e. not ketogenic) diets ${ }^{(114)}$, and their limited effect on body fat point both to a generalised inefficiency of the so-called 'high-protein' diets ${ }^{(115)}$ and support the relative danger of their uncontrolled application.

One of the most important aspects of amino acid metabolism is the synergistic complementarity of the roles of a number of peripheral organs, the liver and the rest of splanchnic bed organs ${ }^{(116,117)}$. Hyperproteic diets may induce changes in their roles in the absence of energy overload, i.e. under conditions of active amino acid catabolism $^{(118)}$. However, it is highly improbable that the finely adjusted inter-organ relationships could be maintained under the pressure of high-energy diets, as the low urea output seems to indicate; as a consequence the whole body is affected by an excess of 2-amino-N.

There are few data on human subjects supporting an increase in the synthesis of $\mathrm{NO}^{*}$ in high-energy availability conditions, except for an increased breath release of $\mathrm{NO}^{\cdot(81)}$ and the consequent formation of nitrite and nitrate $^{(93,94)}$. Perhaps the high levels of nitrite and the easy interconversion of nitrite and $\mathrm{NO}^{\cdot(99,119)}$, a powerful vasodilator $^{(120)}$, may be related to the 'obesity paradox', i.e. a decreased severity of the consequences of heart failure in the obese ${ }^{(121,122)}$. The large presence of $\mathrm{NO}_{\mathrm{x}}$ in the alimentary canal and its profound influence on the microbiota has to produce, necessarily, changes in their properties and functions: at least a different way to cope with unused substrates and different relationships with the immune systemcontrolled intestinal barrier. The latter may be related to the higher levels of circulating lipopolysaccharide observed in the metabolic syndrome ${ }^{(123)}$, also linked to the maintenance of low-key inflammation ${ }^{(124,125)}$ caused by increased intestinal bacteria activity ${ }^{(126)}$. These findings hint to the postulated excess 2-amino-N, in agreement with the higher availability of amino acids and energy to increase protein turnover $^{(127,128)}$ and to maintain a fully functional immune system $^{(129)}$ observed in the metabolic syndrome.

\section{Conclusions}

Humans are fairly well prepared for amino-N scarcity: dietary protein utilisation is maximised, and amino acid catabolism is restricted in order to preserve body protein, and, with that, to maintain the ability to function and survive. However, the same mechanisms that make possible sparing amino acid catabolism for energy seriously hamper the metabolism of excess dietary amino- $\mathrm{N}$ under conditions of overfeeding and excess available energy. Insulin resistance limits the use of glucose when fats are readily available, and ample glucose (energy) availability practically blocks the removal of amino-N to form ammonia, the only, and narrow, canonical way to dispose of excess $\mathrm{N}$. The obese excrete less urea than the lean, high-energy diets inhibit the urea cycle function, but also alter the glucose-alanine cycle and the operation of the purine nucleotide cycle; the path of conversion of amino-N to ammonium is severely restricted. This creates a surplus amino acid availability which enhances growth and protein synthesis, but protein turnover simply stores, and transamination changes, the hydrocarbon skeletons, preserving the amino groups. Consequently, non-conventional mechanisms are necessarily activated (there is no body storage of this surplus $\mathrm{N}$ ). We do not know how this is accomplished, and only can suggest the possible implication of $\mathrm{NO}^{\circ}$-increased synthesis, followed by higher nitrite (and nitrate) secretion/excretion, and including the production of $\mathrm{N}_{2}$ gas, through a mechanism so far unsolved.

The metabolic consequences of the imbalance between amino- and ammonia-N are far-reaching and should be studied in detail, since probably a number of unexplained phenomena of the metabolic syndrome sink their roots in the profound alteration of $\mathrm{N}$ homeostasis. The consequences of excess dietary protein and our inability to dispose of it have not been studied, but the indications obtained from animal studies and the few data available suggest that excess protein is harmful in the long term for humans.

\section{Acknowledgements}

The present review was supported by grant no. SAF200911739 of the Plan Nacional de Investigación en Biomedicina of the Government of Spain. There are no conflicting interests to disclose.

\section{References}

1. Felig P, Owen OE, Wahren J, et al. (1969) Amino acid metabolism during prolonged starvation. J Clin Invest 48, 584-594. 
2. Goodman MN, Belur E, Lowell B, et al. (1984) Sites of protein conservation and loss during starvation. Influence of adiposity. Am J Physiol 246, E383-E390.

3. Smith SR, Pozefsky T \& Chhetri MK (1974) Nitrogen and amino acid metabolism in adults with protein-calorie malnutrition. Metabolism 23, 603-618.

4. Frenk S (1986) Metabolic adaptation in protein-energy malnutrition. J Am Coll Nutr 5, 371-381.

5. Scalfi L, Alfieri R, Borrelli R, et al. (1987) Protein balance during very-low-calorie diets for the treatment of severe obesity. Ann Nutr Metab 31, 154-159.

6. Gougeon R, Hoffer LJ, Pencharz PB, et al. (1992) Protein metabolism in obese subjects during a very-low-energy diet. Am J Clin Nutr 56, S249-S254.

7. Doherty JU, Wadden TA, Zuk L, et al. (1991) Long-term evaluation of cardiac function in obese patients treated with a very-low-calorie diet. A controlled clinical study of patients without underlying cardiac disease. Am J Clin Nutr 53, 854-858.

8. Johnstone AM, Horgan GW, Murison SD, et al. (2008) Effects of a high-protein ketogenic diet on hunger, appetite, and weight loss in obese men feeding ad libitum. Am J Clin Nutr 87, 44-55.

9. Willi SM, Oexmann MJ, Wright NM, et al. (1998) The effects of a high-protein, low-fat, ketogenic diet on adolescents with morbid obesity: body composition, blood chemistries, and sleep abnormalities. Pediatrics 101, 61-67.

10. Yancy WS, Olsen MK, Guyton JR, et al. (2004) A low-carbohydrate, ketogenic diet versus a low-fat diet to treat obesity and hyperlipidemia. A randomized, controlled trial. Ann Intern Med 140, 769-777.

11. Sankar R \& Sotero de Menezes M (1999) Metabolic and endocrine aspects of the ketogenic diet. Epilepsy Res 37, 191-201.

12. Masanés RM, Fernández-López JA, Alemany M, et al. (1999) Effect of dietary protein content on tissue protein synthesis rates in Zucker lean rats. Nutr Res 19, 1017-1026.

13. Uebanso T, Taketani Y, Fukaya M, et al. (2009) Hypocaloric high-protein diet improves fatty liver and hypertriglyceridemia in sucrose-fed obese rats via two pathways. Am J Physiol 297, E76-E84.

14. Frassetto LA, Schloetter M, Mietus-Synder M, et al. (2009) Metabolic and physiologic improvements from consuming a paleolithic, hunter-gatherer type diet. Eur J Clin Nutr 63, 947-955.

15. Eaton SB \& Eaton SB III (2000) Paleolithic $v$. modern diets - selected pathophysiological implications. Eur J Nutr 39, $67-70$.

16. Brooks SPJ \& Lampi BJ (1995) The effect of changing dietary fat and carbohydrate on the enzymes of amino acid metabolism. J Nutr Biochem 6, 414-421.

17. Oke BO \& Loerch SC (1992) Effects of energy and amino acid supply to the small intestine on amino acid metabolism. J Nutr Biochem 3, 62-66.

18. Hart DW, Wolf SE, Zhang XJ, et al. (2001) Efficacy of a highcarbohydrate diet in catabolic illness. Crit Care Med 29, 1318-1324.

19. Kawaguchi T, Osatomi K, Yamashita H, et al. (2002) Mechanism for fatty acid 'sparing' effect on glucoseinduced transcription. Regulation of carbohydrateresponsive element-binding protein by AMP-activated protein kinase. J Biol Chem 277, 3829-3835.

20. Stoll B, Henry J, Reeds PJ, et al. (1998) Catabolism dominates the first-pass intestinal metabolism of dietary essential amino acids in milk protein-fed piglets. J Nutr 128, 606-614.
21. Wolfram S \& Scharrer E (1984) Effect of feeding a high protein diet on amino acid uptake into rat intestinal brush border membrane vesicles. Pflügers Archiv 400, 34-39.

22. Esteve M, Rafecas I, Fernández-López JA, et al. (1993) Dietary amino acid balances in young Wistar rats fed a cafeteria diet. Biochem Mol Biol Int 29, 1069-1081.

23. Cahová M, Vavrínková H, Kazdová L, et al. (2007) Glucosefatty acid interaction in skeletal muscle and adipose tissue in insulin resistance. Physiol Res 56, 1-15.

24. Shinnick FL \& Harper AE (1976) Branched-chain amino acids oxidation by isolated rat tissue preparations. Biochim Biophys Acta 437, 477-486.

25. Goodman MN \& Lowenstein JM (1977) The purine nucleotide cycle - studies of ammonia production by skeletal muscle in situ and in perfused preparations. $J$ Biol Chem 252, 5054-5060.

26. Tornheim K \& Lowenstein JM (1975) The purine nucleotide cycle. Control of phosphofructokinase and glycolytic oscillations in muscle extracts. J Biol Chem 250, 6304-6314.

27. Atkinson DE \& Walton GM (1967) Adenosine triphosphate conservation in metabolic regulation. Rat liver citrate cleavage enzyme. J Biol Chem 242, 3239-3241.

28. Núñez de Castro I, Arias-Saavedra JM, Machado A, et al (1974) Effect of inhibitors of mitochondrial protein synthesis on the NADH and NADPH glutamate dehydrogenases in yeast. Mol Cell Biochem 3, 109-111.

29. Batrel Y \& Regnault M (1985) Metabolic pathways of ammoniagenesis in the shrimp Crangon crangon L.: possible role of glutamate dehydrogenase. Comp Biochem Physiol 82B, 217-222.

30. Lowenstein JM (1972) Ammonia production in muscle and other tissues: the purine nucleotide cycle. Physiol Rev $\mathbf{5 2}$ 382-414.

31. Arola L, Palou A, Remesar X, et al. (1979) $\mathrm{NADH}$ and $\mathrm{NADPH}$ dependent glutamate dehydrogenase activities in the organs of the rat. IRCS Med Sci 7, 364.

32. Remesar X, Arola L, Palou A, et al. (1980) Distribution of glutamate dehydrogenase activity in the organs of fed and 24 hour fasted rats. IRCS Med Sci 8, 146.

33. McGivan JD \& Chappell JB (1975) On the metabolic function of glutamate dehydrogenase in rat liver. FEBS Lett $\mathbf{5 2}$ $1-7$.

34. Schoolwerth AC, Nazar BL \& LaNoue KF (1978) Glutamate dehydrogenase activation and ammonia formation by rat kidney mitochondria. J Biol Chem 254, 6177-6183.

35. Bailey J, Bell ET \& Bell E (1982) Regulation of bovine glutamate dehydrogenase. The effects of $\mathrm{pH}$ and ADP. J Biol Chem 257, 5579-5583.

36. Flanagan WF, Holmes EW, Sabina RL, et al. (1986) Importance of purine nucleotide cycle to energy production in skeletal muscle. Am J Physiol 251, C795-C802.

37. Marliss EB, Aoki TT, Pozefsky T, et al. (1971) Muscle and splanchnic glutamine and glutamate. Metabolism in postabsorptive and starved man. J Clin Invest 50, 814-817.

38. Wu GY (1998) Intestinal mucosal amino acid catabolism. J Nutr 128, 1249-1252.

39. Good DW \& Burg MB (1984) Ammonia production by individual segments of the rat nephron. J Clin Invest 73, 602-610.

40. Karasawa Y \& Nakata C (1986) Ammonia absorption from different parts of chicken intestine and its quantitative evaluation in situ. Comp Biochem Physiol 84A, 747-750.

41. Wrong OM \& Vince A (1984) Urea and ammonia metabolism in the human large intestine. Proc Nutr Soc 43, 77-86.

42. Anderson NM, Bennett FI \& Alleyne GAO (1976) Ammonia production by the small intestine of the rat. Biochim Biophys Acta 437, 238-243. 
43. Weber FL, Veach G \& Friedman DW (1982) Stimulation of ammonia production from glutamine by intraluminal glucose in small intestine of dogs. Am J Physiol 242, G552-G557.

44. Barber T, Viña JR, Viña J, et al. (1985) Decreased urea synthesis in cafeteria-diet-induced obesity in the rat. Biochem J 230, 675-681.

45. Esteve M, Rafecas I, Remesar X, et al. (1991) Nitrogen balances of lean and obese Zucker rats subjected to a cafeteria diet. Int J Obes 16, 237-244.

46. Serra F, Gianotti M, Palou A, et al. (1991) Dietary obesity shows adaptations of amino-acid metabolism on enzyme activities to save amino nitrogen. Biochem Int $\mathbf{2 4}$, $769-776$.

47. Esteve M, Rafecas I, Remesar X, et al. (1992) Nitrogen balance discrepancy in Wistar rats fed a cafeteria diet. Biochem Int 26, 687-694.

48. Costa G, Ullrich L, Kantor F, et al. (1988) Production of elemental nitrogen by certain mammals including man. Nature 218, 546-551.

49. Cissik JH, Johson RE \& Rokosch DK (1972) Production of gaseous nitrogen in human steady-state conditions. $J$ Appl Physiol 32, 155-159.

50. Green LC, Ruiz de Luzuriaga K, Wagner DA, et al. (1981) Nitrate biosynthesis in man. Proc Nat Acad Sci U S A $\mathbf{7 8}$ $7764-7768$

51. Sutton JR, Toews CJ, Ward GR, et al. (1980) Purine metabolism during strenuous muscular exercise in man. Metabolism 29, 254-260.

52. Desir G, Bratusch-Marrain P \& DeFronzo RA (1986) Effect of hyperketonemia on renal ammonia excretion in man. Metabolism 35, 736-743.

53. Robin ED, Travis DM, Bromberg PA, et al. (1959) Ammonia excretion by mammalian lung. Science 129, 270-271.

54. Turner N, Bruce CR, Beale SM, et al. (2007) Excess lipid availability increases mitochondrial fatty acid oxidative capacity in muscle. Evidence against a role for reduced fatty acid oxidation in lipid-induced insulin resistance in rodents. Diabetes 56, 2085-2092.

55. Lam YY, Hatznikolas G, Weir JM, et al. (2011) Insulin-stimulated glucose uptake and pathways regulating energy metabolism in skeletal muscle cells: the effects of subcutaneous and visceral fat, and long-chain saturated, $n-3$ and n-6 polyunsaturated fatty acids. Biochim Biophys Acta 1811, 468-475.

56. Bruce CR, Thrush AB, Mertz VA, et al. (2006) Endurance training in obese humans improves glucose tolerance and mitochondrial fatty acid oxidation and alters muscle lipid content. Am J Physiol Endocrinol Metab 291, E99-E107.

57. Graham T, Bangsbo J \& Saltin B (1993) Skeletal muscle ammonia production and repeated, intense exercise in humans. Can J Physiol Pharmacol 71, 484-490.

58. Moncada S, Palmer RMJ \& Higgs EA (1991) Nitric oxide: physiology, pathophysiology, and pharmacology. Pharmacol Rev 43, 109-142.

59. Mouillé B, Robert V \& Blachier F (2004) Adaptative increase of ornithine production and decrease of ammonia metabolism in rat colonocytes after hyperproteic diet ingestion. Am J Physiol Gastrointest Liver Physiol 287, G344-G351.

60. Tujioka K, Lyou S, Hirano E, et al. (2002) Role of $N$-acetylglutamate concentration on ornithine transport into mitochondria in urea synthesis of rats given proteins of different quality. J Agric Food Chem 50, 7467-7471.

61. Saheki T, Ohkubo T \& Katsunuma T (1978) Regulation of urea synthesis in rat liver. Increase in the concenrations of ornithine and acetylglutamate in rat liver in response to urea synthesis stimulated by the injection of an ammonium salt. $J$ Biochem 84, 1423-1430.

62. Moncada S \& Higgs A (1993) The L-arginine-nitric oxide pathway. N Engl J Med 329, 2002-2012.

63. McCall TB, Boughton-Smith NK, Palmer RM, et al. (1989) Synthesis of nitric oxide from L-arginine by neutrophils. Release and interaction with superoxide anion. Biochem J 26, 293-296.

64. Herrero MC, Angles N, Remesar X, et al. (1994) Splanchnic ammonia management in genetic and dietary obesity in the rat. Int J Obes 18, 255-261.

65. Roig R, Esteve M, Remesar X, et al. (1997) Regulation of ammonia-metabolizing enzymes expression in the liver of obese rats: differences between genetic and nutritional obesities. Int J Obes 21, 681-685.

66. Kleinbongard P, Schultz R, Rassaf T, et al. (2006) Red blood cells express a functional endothelial nitric oxide synthase. Blood 107, 2943-2951.

67. Sureda A, Tauler P, Aguiló A, et al. (2006) Blood cell NO synthesis in response to exercise. Nitric Oxide 15, 5-12.

68. Arnold WP, Mittal CK, Katsuki S, et al. (1977) NO activates guanylate cyclase and increases guanosine $3^{\prime}: 5^{\prime}$-cyclic monophosphate levels in various tissue preparations. Proc Nat Acad Sci U S A 74, 3203-3207.

69. Francis SH, Busch JL \& Corbin JD (2010) cGMP-dependent protein kinases and cGMP phosphodiesterases in nitric oxide and cGMP action. Pharmacol Rev 62, 525-563.

70. Lincoln TM, Komalavilas P \& Cornwell TL (1994) Pleiotropic regulation of vascular smooth muscle tone by cyclic GMP-dependent protein kinase. Hypertension $\mathbf{2 3}$, 1141-1147.

71. Sessa WC (2009) Molecular control of blood flow and angiogenesis: role of nitric oxide. J Thromb Hemost 7, 35-37.

72. Ferro A, Coash M, Yamamoto T, et al. (2004) Nitric oxidedependent $\beta_{2}$-adrenergic dilatation of rat aorta is mediated through activation of both protein kinase A and Akt. $\mathrm{BrJ}$ Pharmacol 143, 397-403.

73. Burgoyne JR \& Eaton P (2009) Transnitrosylating NO species directly activate type I protein kinase A, providing a novel adenylate cyclase-independent cross-talk to $\beta$ adrenergic-like signaling. J Biol Chem 284, 29260-29268.

74. Torres J, Sharpe MA, Rosquist A, et al. (2000) Cytochrome $c$ oxidase rapidly metabolises nitric oxide to nitrite. FEBS Lett 475, 263-266.

75. Gow AJ, Luchsinger BP, Pawloski JR, et al. (1999) The oxyhemoglobin reaction of nitric oxide. Proc Nat Acad Sci U S A 96, 9027-9032.

76. Huie RE \& Padmaja S (1993) The reaction of NO with superoxide. Free Rad Res Commun 18, 195-199.

77. Trostchansky A \& Rubbo H (2008) Nitrated fatty acids: mechanisms of formation, chemical characterization, and biological properties. Free Radic Biol Med 44, 1887-1896.

78. Rubbo H \& Radi R (2008) Protein and lipid nitration: role in redox signaling and injury. Biochim Biophys Acta 1780, 1318-1324.

79. Jain K, Siddam A, Marathi A, et al. (2008) The mechanism of oleic acid nitration by $\cdot \mathrm{NO}_{2}$. Free Radic Biol Med 45 , 269-283.

80. Asl SZ, Ghasemi A \& Azizi F (2008) Serum nitric oxide metabolites in subjects with metabolic syndrome. Clin Biochem 41, 1342-1347.

81. Maniscalco M, de Laurentiis G, Zedda A, et al. (2007) Exhaled nitric oxide in severe obesity: effect of weight loss. Resp Physiol Neurobiol 156, 370-373.

82. Cissik JH, Johnson RE \& Hertig BA (1972) Production of gaseous nitrogen during human steady state exercise. Aerospace Med 43, 1245-1250. 
83. Schmidt CLA (1929) The reaction between nitrous acid and certain amino acids related compounds at $45^{\circ}$. J Biol Chem 82, 587-594.

84. Yoshida K \& Kasama K (1987) Biotransformation of nitric oxide. Environm Health Perspect 73, 201-206.

85. Worrall NK, Misko TP, Sullivan PM, et al. (1996) Corticosteroids inhibit expression of inducible nitric oxide synthase during acute cardiac allograft rejection. Transplantation 61, 324-328.

86. Lin WC, Tsai PS \& Huang CJ (2005) Catecholamines' enhancement of inducible nitric oxide synthase-induced nitric oxide biosynthesis involves CAT-1 and CAT-2A. Anesth Analg 101, 226-232.

87. Hall JE (2000) Pathophysiology of obesity hypertension. Curr Hypertens Rep 2, 139-147.

88. Elizalde M, Rydén M, van Harmelen V, et al. (2000) Expression of nitric oxide synthesis in subcutaneous adipose tissue of nonobese and obese humans. J Lipid Res 41, 1244-1251.

89. Blouet C, Mariotti F, Mathe V, et al. (2007) Nitric oxide bioavailability and not production is first altered during the onset of insulin resistance in sucrose-fed rats. Exp Biol Med 232, 1458-1464.

90. Williams IL, Wheatcroft SB, Shah AM, et al. (2002) Obesity, atherosclerosis and the vascular endothelium: mechanisms of reduced nitric oxide bioavailability in obese humans. Int J Obesity 26, 754-764.

91. Tsuchiya K, Kanematsu Y, Yoshizumi M, et al. (2004) Nitrite is an alternative source of $\mathrm{NO}$ in vivo. Am J Physiol Heart Circ Physiol 288, H2163-H2170.

92. Piknova B, Keszler A, Hogg N, et al. (2009) The reaction of cell-free oxyhemoglobin with nitrite under physiologically relevant conditions. Implications for nitrite-based therapies. Nitric Oxide 20, 88-94.

93. Kim-Shapiro DB, Schechter AN \& Gladwin MT (2006) Unraveling the reactions of nitric oxide, nitrite, and hemoglobin in physiology and therapeutics. Arterioscler Thromb Vasc Biol 26, 697-705.

94. Lundberg JO, Weitzberg E \& Gladwin MT (2008) The nitrate-nitrite-nitric oxide pathway in physiology and therapeutics. Nat Rev Drug Discov 7, 156-167.

95. Ingram TE, Pinder AG, Bailey DM, et al. (2010) Low-dose sodium nitrite vasodilates hypoxic human pulmonary vasculature by a means that is not dependent on a simultaneous elevation in plasma nitrite. Am J Physiol Heart Circ Physiol 298, H331-H339.

96. Eckmann L, Jaurent F, Langford TD, et al. (2000) Nitric oxide production by human intestinal epithelial cells and competition for arginine as potential determinants of host defense against the lumen-dwelling pathogen Giardia lamblia. J Immunol 164, 1478-1487.

97. Lundberg JO, Weitzberg E, Lundberg JM, et al. (1994) Intragastric nitric oxide production in humans: measurements in expelled air. Gut 35, 1543-1546.

98. Chen C, Ren F, Lu T, et al. (2010) Involvement of salivary glands in regulating the human nitrate and nitrite levels. Arch Oral Biol 55, 613-620.

99. Iijima K, Fyfe V \& McColl KEL (2003) Studies of nitric oxide generation from salivary nitrite in human gastric juice. Scand J Gastroenterol 38, 246-252.

100. Ishibashi T \& Kawabata T (1981) Formation of N-nitrosoproline by reacting nitrite with L-citrulline and L-arginine. J Agric Food Chem 29, 1099-1089.

101. Cani PD, Possemiers S, van de Wiele T, et al. (2009) Changes in gut microbiota control inflammation in obese mice through a mechanism involving GLP-2-driven improvement of gut permeability. Gut 58, 1091-1103.
102. Brignardello J, Morales P, Diaz E, et al. (2010) Pilot study: alterations of intestinal microbiota in obese humans are not associated with colonic inflammation or disturbances of barrier function. Alim Pharmacol Ther $\mathbf{3 2}$, 1307-1314.

103. Dykhuizen RS, Frazer R, Duncan C, et al. (1996) Antimicrobial effect of acidified nitrite on gut pathogens: importance of dietary nitrate in host defense. Antimicrob Agents Chemother 40, 1422-1425.

104. Manco M, Putignani L \& Bottazzo GF (2010) Gut microbiota, lipopolysaccharides, and innate immunity in the pathogenesis of obesity and cardiovascular risk. Endocr Rev 31, 817-844.

105. Vaarala O, Atkinson MA \& Neu J (2008) The 'perfect storm' for type 1 diabetes. The complex interplay between intestinal microbiota, gut permeability, and mucosal immunity. Diabetes 57, 2555-2562.

106. Harmon BG, Becker DE, Jensen AH, et al. (1968) Influence of microbiota on metabolic fecal nitrogen in rats. J Nutr $\mathbf{9 6}$, 391-396.

107. Hughes R, Magee EAM \& Bingham S (2000) Protein degradation in the large intestine: relevance to colorectal cancer. Curr Iss Intest Microbiol 1, 51-58.

108. Bingham SA, Pignatelli B, Pollock JRA, et al. (1996) Does increased endogenous formation of $\mathrm{N}$-nitroso compounds in the human colon explain the association between red meat and colon cancer? Carcinogenesis 17, 515-523.

109. Lee K, Lee J, Bae WK, et al. (2009) Efficacy of low-calorie, partial meal replacement diet plans on weight and abdominal fat in obese subjects with metabolic syndrome: a double-blind, randomised controlled trial of two diet plans - one high in protein and one nutritionally balanced. Int J Clin Pract 63, 195-201.

110. Pasiakos SM, Mettel JB, West K, et al. (2008) Maintenance of resting energy expenditure after weight loss in premenopausal women: potential benefits of a high-protein, reduced-calorie diet. Metabolism 57, 458-464.

111. Schloeder FX \& Stinebaugh BJ (1977) Urinary ammonia content as a determinant of urinary $\mathrm{pH}$ during chronic metabolic acidosis. Metabolism 26, 1321-1331.

112. Simon E, Martin D \& Buerkert J (1983) Handling of ammonium by the renal proximal tubule during acute metabolic acidosis. Am J Physiol Renal Physiol 245, F680-F686.

113. Sherwin RS, Hendler RG \& Felig P (1975) Effect of ketone infusions on amino acid and nitrogen metabolism in man. J Clin Invest 55, 1382-1390.

114. Metges CC \& Barth CA (2000) Metabolic consequences of a high dietary-protein intake in adulthood: assessment of the available evidence. J Nutr 130, 886-889.

115. Johnstone AM (2009) High-protein diets for appetite control and weight loss - the 'holy grail' of dieting? Br J Nutr 101, $1729-1730$

116. Aikawa T, Matsutaka H, Takezawa K, et al. (1972) Gluconeogenesis and amino acid metabolism 1. Comparison of various precursors for hepatic gluconeogenesis in vivo. Biochim Biophys Acta 279, 234-244.

117. Felig P (1973) The glucose-alanine cycle. Metabolism 22, 179-207.

118. Morens C, Gaudichon C, Fromentin G, et al. (2001) Daily delivery of dietary nitrogen to the periphery is stable in rats adapted to increased protein intake. Am J Physiol Endocrinol Metab 281, E826-E896.

119. Gladwin MT, Crawford JH \& Patel RP (2004) The biochemistry of nitric oxide, nitrite, and hemoglobin: role in blood flow regulation. Free Radic Biol Med 36, 707-717. 
120. Rees DD, Palmer RM \& Moncada S (1989) Role of endothelium-derived nitric oxide in the regulation of blood pressure. Proc Nat Acad Sci USA 86, 3375-3378.

121. Gruberg L, Weissman NJ, Waksman R, et al. (2002) The impact of obesity on the short-term and long-term outcomes after percutaneous coronary intervention: the obesity paradox? J Am Coll Cardiol 39, 578-584.

122. Badheka AO, Rathod A, Kizilbash MA, et al. (2010) Influence of obesity on outcomes in atrial fibrillation: yet another obesity paradox. Am J Med 123, 646-651.

123. Brun P, Castagliuolo I, di Leo V, et al. (2007) Increased intestinal permeability in obese mice: new evidence in the pathogenesis of nonalcoholic steatohepatitis. Am J Physiol 292, G518-G525.

124. Cancello R \& Clément K (2006) Is obesity an inflammatory illness? Role of low-grade inflammation and macrophage infiltration in human white adipose tissue. $\mathrm{Br} J$ Obstet Gynaecol 113, 1141-1147.

125. Matsuo Y, Hashizume T, Shioji S, et al. (2008) Metabolic syndrome is strongly associated with chronic subclinical inflammation in patients achieving optimal low-density lipoprotein-cholesterol levels in secondary prevention of cardiovascular disease. Circ J 72, 2046-2050.
126. Sabate JM, Jouet $\mathrm{P}$, Harnois F, et al. (2008) High prevalence of small intestinal bacterial overgrowth in patients with morbid obesity: a contributor to severe hepatic steatosis. Obes Surg 18, 371-377.

127. Robinson SM, Jaccard C, Persaud C, et al. (1990) Proteinturnover and thermogenesis in response to high-protein and high-carbohydrate feeding in men. Am J Clin Nutr 52, 72-80

128. Yuile CL, Lucas EV, Olson JP, et al. (1959) Plasma protein turnover and tissue exchange. Influence of dietary protein and protein depletion. $J$ Exp Med 109, 173-186.

129. Dunca BB \& Schmidt MI (2001) Chronic activation of the innate immune system may underlie the metabolic syndrome. S Paulo Med J 119, 122-127.

130. Ferrer-Lorente R, Fernández-López JA \& Alemany M (2007) Estimation of the metabolizable energy equivalence of dietary proteins. Eur J Nutr 46, 1-11.

131. Food Policy and Food Science Service (1981) Amino-Acid Content of Foods and Biological Data on Proteins. Rome: FAO.

132. Rafecas I, Esteve M, Fernández-López JA, et al. (1994) Whole rat protein content estimation. Applicability of the $\mathrm{N} \times 6.25$ factor. Br J Nutr 72, 199-209. 